\title{
The Application of Organica Ecological Technology in Residential Sewage Treatment
}

\author{
Qin Yuje ${ }^{1,2,3}$, Wu Jiandong ${ }^{1}$, Ouyang Hai ${ }^{1}$ \\ ${ }^{1}$ College of Environmental Science and Engineering, South China University of Technology, Guangzhou, China; ${ }^{2}$ State Key Labora- \\ tory Subtropical Building Science, Guangzhou, China; ${ }^{3}$ The Key Lab of Pollution Control and Ecosystem Restoration in Industry \\ Clusters, Ministry of Education, South China University of Technology, Guangzhou, China. \\ Email: qinyujie@scut.edu.cn
}

Received 2013

\begin{abstract}
Water is the basis in ecological residential area. It is very important to recycle the water resource in the designing and planning of the ecological residential quarter due to the critical way to realize the wastewater resource utilization. In this paper, a new technology of wastewater treatment is introduced, which is ORGANICA ecotechnology. We integrate the traditional wastewater treatment technology and modern ecological engineering technology together and apply the integrated technology in the treatment of domestic sewage. The treated water can be reused for landscape and greening, which can beautify the residential area and recycle wastewater.
\end{abstract}

Keywords: ORGANICA Technology; Ecological Residence; Water Recycle

\section{Introduction}

The shortage of water resources has become a globally serious problem. The sewage after appropriate treatment and the reuse of the recycled water have become the consensus of all over the world. The wastewater reclamation and reuse, in the existing sewage concentrated treatment, need, will the process which is similar to the water supply pipe network city recycled water distribution system, after the network system and a series of midway lifting pump stations and distribution to users. Thus, the urban pipeline system occurs at least three times in conveying. However, the conveying process wastes a large amount of capital cost and operation cost. This part of the investment has become a huge economic burden and more than the cost of urban sewage concentrated treatment plant, and due to the leakage problems on water resources will also cause the second pollution. Sewage concentrated treatment obviously has its limitations, at present many water treatment scientists are actively advocate "in situ treatment in situ, and to realize the reuse water balance and water circulation system" [1].

In recent years, a new processing system, which is called the distributed processing and reuse system, start to be used widely in some countries, especially in the Netherlands, Germany, Scandinavia areas. It can overcome the shortage of the centralized wastewater treatment system by using this system [2]. Ecological resi- dential quarter wastewater treatment is sewage dispersion processing mainly reflects, the plot sewage in situ collection, processing and recycling, processing more than centralized economic and feasible. Thus, the water pollution not only can be controlled, but also in situ treatment after specific reuse, saving a large amount of the water resources in order to meet the requirements of sustainable development; At the same time, it can also obtain good economic benefit. There are many kinds of quarter sewage treatment method. By using the latest foreign advanced technology, named ORGANICA ecological treatment technology, combining the latest engineering technology and the traditional wastewater treatment technology together, has the broad prospect.

\section{Present Situation of Ecological Residential Sewage Reuse at Home and Abroad}

There are more than 20 years of history for the construction of foreign ecological residence sewage reuse, and there are many experiences. Many countries have formed their characteristics. According to their own national conditions and adopting different technical means to solve the problem of resources and energy, meeting or satisfying partly due to water shortage limit city need to be fairly good social benefits and economic benefits. Denmark is one of earliest country to implement the ecological residential engineering, as early as in the end of 1984, a demonstration project called "not allergic housing" in 
Aarhus. Residential use a series of water saving technology measures, including residential area sewage through the small sewage processor in situ treatment, will become sewage water, make residential area water saving $30 \%$, but also improved the environment of the whole [3]. Each design aimed for maximum limit protecting natural resources and minimal impact on environment in a zero energy consumption community in London, waste water in the community through the small sewage processor system in situ treatment, the wastewater can be recycled [4]. Israel is located in the eastern Mediterranean, with most of the arid and semi-arid area, the country's small community life sewage in situ reuse, $100 \%$ of life sewage reuse [5]. North America is the developed areas using sewage reuse in the world. There are 357 cities reuse sewage, and 536 regeneration recycling stations. Japanese land area is small, the large population, water resources occupancy is lower than the world average level, because Japanese government puts forward the "water" concept, in 1990, and sets up 1369 reuse engineering all over the country [6]. There are 50000 metric tons of recycled water back to used for landscaping, industrial every day in Mecca and Jeddar, Saudi Arabia [7]. The water supply reaches for 1.13 million tons per day, of which $85 \%$ is the use of urban sewage as water each day, 94000 tons of drinking water from regenerative waterworks in Johannesburg, Republic of South Africa. The low polluted sewage is directly used as irrigation, and has achieved good economic benefit in Thessaly, Greek [8].

The ecological residence research, construction and sewage reuse started late in China. Since the 1980s, Chinese architects also made many try, made some preliminary success experience, but need to be widespread to form the situation of large scale development of the ecological residential sewage reuse. The sewage of the new capital manor quarter in Tianjin was treated with all, on craft chose CMR sewage treatment technology, the water processing system treated sewage, used in the water, greening, road flushing, etc., saving the water spending greatly for the people and property management units[9]. At an ecological residential quarter in Haikou, China, the design of sewage treatment adapt soil toilet, kitchen washing wastewater and other life sewage separation of interior drainage pipe processing respectively, forming a residential area sewage purification, rainwater collection, gray water utilization the integrity of the ecological system. In an ecological residential quarter in Shenyang, China, it adopted in depth sewage treatment to realize part of reclaimed water reuse, and created the good benefit [10]. Government pays more and more attention to water recycling, and there are vigorously explore on the reuse technology in each local government, and to make the technology more and more mature.

\section{ORGANICA Technology}

ORGANICA ecological treatment technology was firstly put forward in the United States of America. ORGANICA Company shall be responsible for the later research, development, technology promotion and engineering application. The company was established in 1998, set up in Budapest, Hungary. This technology integrates the modern ecological engineering technology and the traditional wastewater treatment technology as an organic whole.

\subsection{The Principle of ORGANICA Technology}

Wastewater treatment methods used activated sludge. According to the water quality index, process selection A2 / O or A/O process, ecological system in plant fixed with iron rack, the typical process flow see Figure 1.

Wastewater treatment principle is to integrate the traditional activated sludge process and ecological engineering technology as a whole, that is firstly anaerobic, anoxic, and then aerobic reaction. In the aerobic reaction, the whole device vaccinate $2000-3000$ species of plants, animals and microbes, besides the traditional activated sludge system of biological bacteria in vitro. These organisms have self synthesis and the capacity of absorbing the solar energy, which can improve the system to handle ability, improve water quality.

\subsection{The Characteristics of ORGANICA Technology}

ORGANICA technology has traditional activated sludge process characteristic, but also has the following features: (1) the ecological treatment system have 2000-3000 species of plants, animals and microbes, these organisms promote the system processing ability; (2) more kinds of biological system, the variety is complete, the formation of ecological system stability, metabolism ability is strong, can realize quick start; (3) contaminated water in turn cascade flow through the naturalized but have different ecological structure of the processing unit, ensure treatment plant with good ecological purification function and flexibility of operation; (3) appearance design beautiful, have a kind of natural beauty, a decorative flowers and wastewater treatment plant as a plant garden, can be used in the most strict requirement of high-grade community life sewage purification and reuse; (4) the construction investment and operation cost is low and the effluent can meet the greening, flushing and water reuse requirements, but also can be used as ecological landscape make-up water; (5) ORGANICA wastewater ecological treatment device has a snail and other senior animals participate in the treatment process, reduce the amount of excess sludge, reduce sludge treatment cost, built-in biological filter to eliminate the odor pollution. 


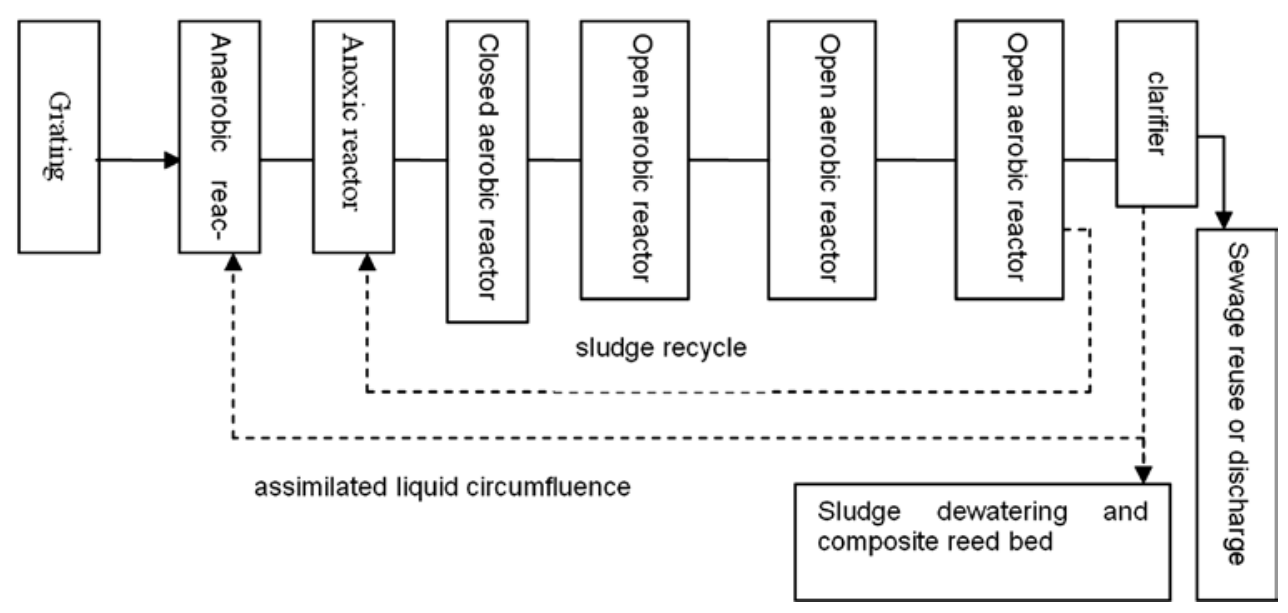

Figure 1. ORGANICA typical process flow diagram.

Compared with the traditional activated sludge process, this system cause has higher system processing capacity, good ecological purification function and operating flexibility and investment and operation cost is low, water reuse recycling value is big, the application range is quite extensive. So if the ecological residential district successfully applied this technology to treat sewage has great economic benefits, ecological benefits and social benefits.

\subsection{ORGANICA Technology Application}

At present this technology in ORGANICA company host country Hungary many places to use, and treatment effect is good, processing water quality can meet our country landscape water standard (GB/T18921-2002). Poland's Notincs three autonomous region also use this technology to treat sewage. ORGANICA ecological treatment technology was used on the purification design of largescale municipal development in Laytown, Ireland. Other countries, such as Ukraine, Russia, and Australia and so on also applied the same technology.

The technology has not been popularized in large-scale in China. Shenzhen was the first city to introduce the technology in 2008. At present it as used in a certain degree in Shenzhen and other cities. The technology performance is very stable from the view of operation. Because the temperature is higher in South China, winter greenhouse don't need heat preservation measures, the plants in a greenhouse to grow in all the year round, the sewage treatment and stable operation, creates the condition is feasible in theory the. To ORGANICA technology in our country ecological residential use of research, there will be a lot of value.

\section{Future Work}

The sewage treatment technology separated the traditional sewage treatment technology from the modern engineer- ing technology in the past. Those treatment technologies mainly discharge the sewage into artificial wetland to the deepening processing which needs two steps and two different places, taking up a large amount of land area. While ORGANICA technology integrates the traditional sewage treatment technology and modern ecological engineering technology as a whole, which can finish sewage treatment in the same place, and achieve water reuse standard. This technology is still not popularized and applied in large scale in China. Currently, it is used tentatively in Shenzhen. Due to the ecological system and the different climatic conditions in China, it is expected to be used in large-scale if the technology is improved according to actual situation.

\section{Achnowledgements}

The author gratefully acknowledges the Nature Science Foundation of Guangdong Province(2012 ZM0042) and the fundamental research funds for the central universities(S2011040005784).

\section{REFERENCES}

[1] P. A. Wildere Decentralized versus centralized wastewater management: decentralized sanitation and reuse-onpts systems and implementation. London UK: IWA Publishing, 2001: pp. 39-54.

[2] S. A.Fane, N. J.Ashbolt, S. B White. Decentralised ruban water reuse: The implications of system scale for cost \& pathogen risk. Water Science and Technology. Vol. 46, No.6-7, 2004, pp. 281-288.

[3] Z. H. Liu, "Ecological residence in North Europe”, Energy Research and Application, Vol. 1, 2004, pp. 21

[4] Y. Weng, “Trend of Development of Foreign Eco-community and Enlightenment to China”, Architectural Journal, Vol. 4, 2006, pp. 32-35.

[5] E. Friedler, O.Lahav, H.Jizhaki, T. Lahay, "Study of urban population attitudes towards various wastewater reuse 
options: Israel as a case study”, Journal of Environmental Management, Vol.81, No.4, 2004, pp. 360-370.

[6] T. Asano, M. Maeda, M. Takaki, "Wastewater reclamation and reuse in Japan: Overview and implementation examples”, Water Science and Technology, Vol. 34, No.11, 2004, pp. 219-226.

[7] O. S. Abu-Rizaiza, "Modification of the standards of Wastewater reuse in Saudi Arabia”, Water Research, Vol. 33, No.11, 2004, pp. 2601-2608.

[8] S. Bakopoulou, C.Emmanouil, A. Kungolos, “Assessment of wastewater effluent quality in Thessaly region, Greece, for determining its irrigation reuse potential”, Ecotoxicology and Environmental Safety, Vol. 74, No.2, 2004, pp. 188-194.

[9] Z. Sun, W. Tang, Y. yang, "the application of the water in the ecological residential area”, Shanxi Architectural, Vol. 33, No. 3, 2007, pp. 192-193.

[10] P. Liu, S. Zhao, R. Wang, "The Ecological Design of Urban Inhabited Environment_— The Ecological Design of Wang-hai-shi-cheng in Haikou", Urban Environment \& Urban Ecology, Vol. 13, No. 4, 2000, pp. 13-16. 